ISSN: 2224-0616

Int. J . Agril. Res. Innov. \& Tech. 4 (1): 53-56, June, 2014

Available online at http:// www.ijarit.webs.com

\title{
PESTICIDE USAGE PATTERN FOR VEGETABLE CULTIVATION IN MANMUNAI SOUTH \& ERUVILPATTU DIVISIONAL SECRETARIAT DIVISION OF BATTICALOA DISTRICT, SRI LANKA
}

\author{
S. Sutharsan*, K. Sivakumar and S. Srikrishnah \\ Received 3 February 2014, Revised 1 June 2014, Accepted 28 June 2014, Published online 30 June 2014
}

\begin{abstract}
Batticaloa, is a coastal district in Sri Lanka. Vegetables except up-country vegetables sold in Batticaloa District are mainly grown in villages. Manmunai South and Eruvilpattu divisional secretariat (DS) division is a predominantly vegetable cultivating area in the Batticaloa district. Farmers in this region use variety of synthetic pesticides to protect vegetables. Recently public concern related to health risks associated with pesticide residues has been increased, substantially. Therefore, a study was conducted to find out pesticide usage practices of farmers on vegetable cultivation in Manmunai South and Eruvilpattu DS division. Stratified random sampling method was used to select respondents' for the survey and the collected data were analyzed statistically. It was observed that, the usage of pesticides was higher in the study area. Vegetable farmers use more than 14 Insecticides to control pest infestation. Farmers in the study area apply pesticides more frequently. Highly pesticide sprayed crop is Brinjal. About $66 \%$ of the Chilli producing farmers and $84 \%$ of the Brinjal producing farmers apply pesticide more than 22 times per cropping season. Around $90 \%$ of the farmers apply more than the recommended dosage and frequency of the pesticides. It was noticed that more than $89 \%$ of the farmers harvest the produce before the recommended pre harvest interval. It was found out that farmers in the study area are not following recommended pesticide usage practices. Hence, it is essential to educate the farmers on recommended pesticide usage practices, reduced usage of synthetic pesticides and use of organic farming practices to reduce the ill effects of synthetic pesticides.
\end{abstract}

Keywords: Pesticide Residues, Questionnaire Survey, Insecticides, Fungicides

Department of Crop Science, Faculty of Agriculture, Eastern University, Sri Lanka, Chenkalady- 30350, Sri Lanka

*Corresponding author's email: sutharsans@esn.ac.lk (S. Sutharsan)

\section{Introduction}

Sri Lanka is an agricultural country as majority of the rural people is still engaged in agriculture for their main livelihood (Vidanapathirana, 2008). Agriculture is an important sector in the economy contributing to $11.1 \%$ as a share of the Gross Domestic Product for the year 2012 (Anonymous, 2013a). In the agricultural sector of Sri Lanka, vegetables are the second most important subsector after rice. Vegetables are produced on a year round basis and a large number of farmers are involved in the production process. Vegetable production is important in many aspects to Sri Lanka and recognized as priority crops in national production enhancement programs (Illankoon et al., 2011).

Batticaloa, a coastal District and central part of Eastern Province of Sri Lanka, falls under the dry zone climatic conditions. Total population in the District is 586,400 (Anonymous, 2013b). Vegetables except up-country vegetables sold in
Batticaloa District are mainly grown in villages. and are harvested and sold fresh. Manmunai south and Eruvilpattu divisional secretariat (DS) division is a predominantly vegetable cultivating area among the 14 DS divisions in Batticaloa District. Farmers in this area use variety of synthetic pesticides to protect vegetable crops from pests and diseases. Recently public concern related to health risks associated with pesticide residues remain in food products has been increased, substantially. Hence, it is essential to find out the current pesticide usage practices of farmers in that area. It is important to carry out awareness programmes to minimize pesticides residues in vegetables. Therefore, this study was performed to find out the pesticide usage pattern for vegetable cultivation by the farmers in the Manmunai South \& Eruvilpattu DS division, the major vegetable producing area, of the Batticaloa District. 


\section{Methodology}

Manmunai South and Eruvil pattu DS division is located in the coastal side of Batticaloa district. There are 45 Grama Niladari (GN) Divisions included under this DS division. Total agricultural land extent in the DS division is 3,555 ha in which 330 ha is used for vegetable cultivation. Major agricultural villages in this DS division are Kaluthavalai, Mankadu, Thettativu and Cheddipalayam.

This survey was carried out from February to April 2013. A number of 387 respondents were selected among the vegetable farmers through stratified random sampling method from the study area. In each GN division, about $10 \%$ of the farm families were randomly selected as sample. Structured questionnaires were designed to gather required information and pretested to assess their suitability. Selected respondents were interviewed at their doorsteps and field observations were also made. The questionnaires were checked for completeness and the data were analyzed using SPSS 11.0.

\section{Results and Discussion}

Major vegetable crops cultivated in the study area

Many economically important vegetable crops are cultivated in the study area. Among them brinjal
(Solanum melongena L.), chilli (Capsicum annum L.), long bean (Vigna unguiculata L.) and okra (Abelmoschus esculentus L.) are the major vegetable crops, which are cultivated by many farmers in larger extent.

\section{Types of pesticides}

It was observed that, the usage of pesticides was higher in the study area. The vegetable farmers use more than 14 type's pesticides to control pest infestation and minimize crop losses. It was also found that, pesticides were applied without adequate knowledge of pest ecology, economic injury levels and type of pesticides to control specific insect pest, their quantities and method of application, pre harvest interval and protective measures. Farmers assume that the only solution to pest problems is to spray more frequently and using different types of pesticides (Dunham, 1995). Several authors (Ngowi et al., 2007; Legutowska et al., 2002) reported that insecticides were the most used pesticides as insect pests are the serious problems in vegetable cultivation. Insecticides were followed by fungicides in usage, indicating that fungal attacks rank second to insect pests. The significant finding is that, vegetable farmers do not spray herbicides. They practice manual weeding with the help of family members.

Table 1. Pesticides used by farmers in the study area

\begin{tabular}{lll}
\hline Pesticides & Generic name & Crops \\
\hline \multirow{4}{*}{ Insecticide } & Abamectin & Chilli \\
& Thimethoxam 20\% +Chlorantraniliprole 20\%(w/w) & Brinjal \\
& Chlorphyrifos & Brinjal, Chilli, Long bean \\
& Imidachlorprid & Brinjal, Chilli, Long bean \\
& Acetamiprid & Brinjal \\
& Profenophos & Chilli, Long bean \\
\hline \multirow{4}{*}{ Fungicide } & Propineb & All vegetables \\
& Mancozeb & All vegetables \\
& Chlorothalonil & All vegetables \\
& Hexaconazole & All vegetables
\end{tabular}

It was common in this study that the labour division including women, children and all farming community exposed to pesticides. The high dependence on pesticides by vegetable farmers in the study area is an indication that they are not aware of other pest management strategies that are effective, inexpensive and environment friendly. There is an urgent need to bring the attention of these farmers to existing alternative pest management strategies that are cost effective and environment friendly (Hummel et al., 2002).

\section{Frequency of application}

Farmers in the study area apply pesticides more frequently since pest infestation is relatively higher in vegetable crops, particularly in chilli, brinjal, long bean and okra. (Fig. 1). Highly pesticide sprayed crop is brinjal. About $84 \%$ of the brinjal farmers apply pesticides more than 22 times for one growing season. Varela et al. (1988) reported that, farmers tend to overuse chemicals by increasing pesticide quantity and spray frequency as well as applying pesticide cocktails. In general, the frequencies of pesticides application by farmers were higher in the study area. Such heavy use of pesticides may result in frequent contact with pesticides, which can lead to significant health problems. Excessive application of pesticides may lead to high levels of concentration on the plants, which may be dangerous to the farmers themselves and to consumers of the final product. 


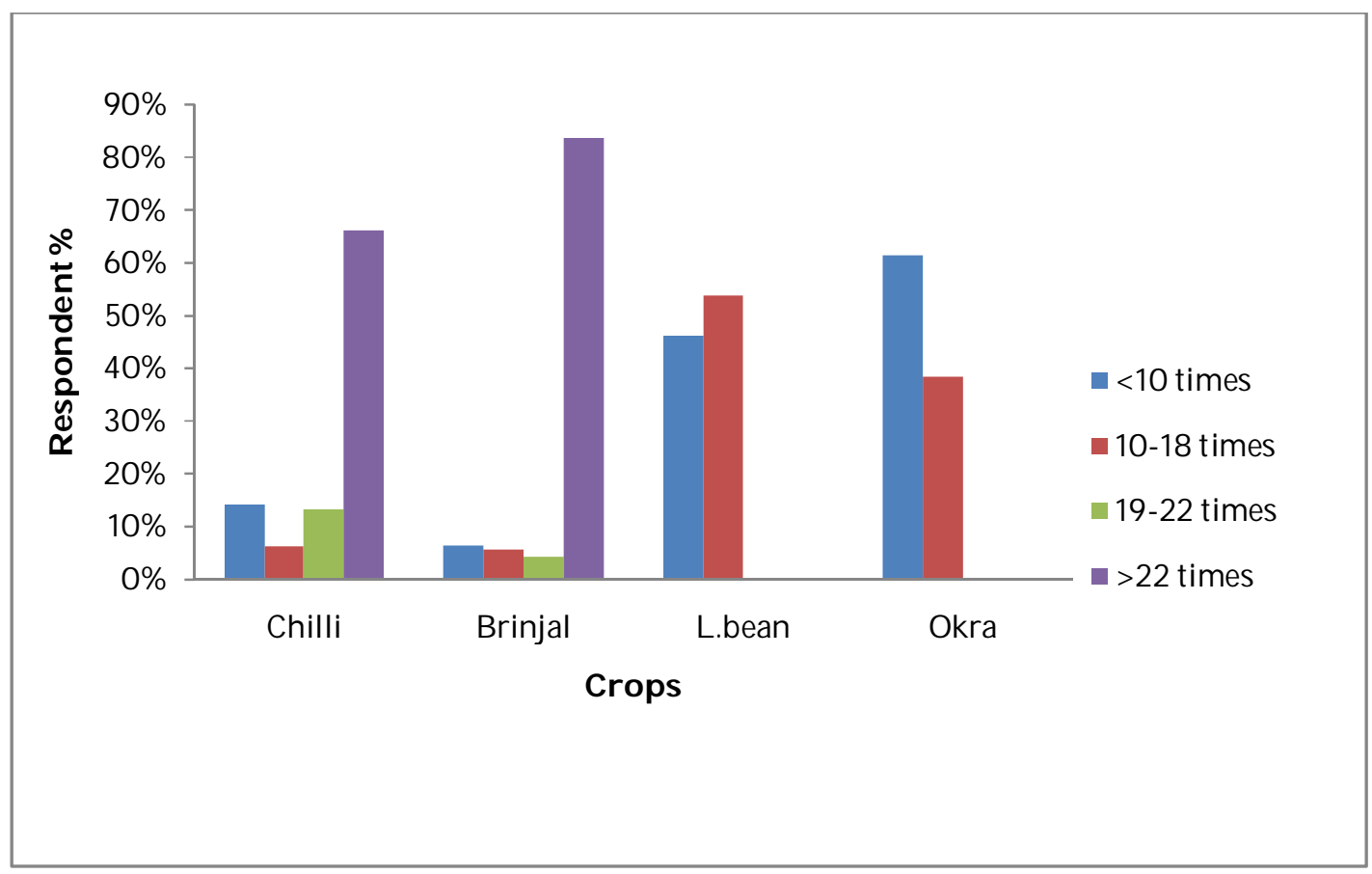

Fig.1. Frequency of pesticide application on the selected vegetables

\section{Dosage of pesticide}

About $90 \%$ of the farmers use more amount of pesticide than the recommendation to dilute with water in the study area. About $4 \%$ of the respondents follow the instruction given by the label, they dilute to the recommended level (Fig. 2). Especially for chilli and brinjal farmers use higher dosages of pesticides than recommendation. Farmers reluctant to follow the recommended dilution as prescribed on the label.

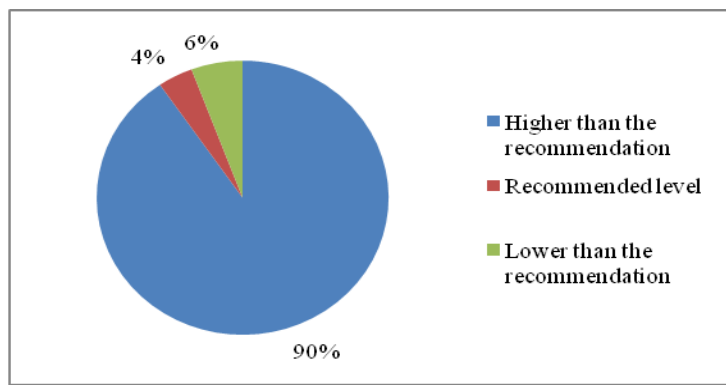

Fig. 2. Dosage of pesticides used by farmers

Some respondent said that they use excessive dosage of chemicals as their neighbour is using the same dosage. They also believe that excessive use of pesticides will give more yields. Resistance of pests to chemicals due to long-term application also made the farmers to use over dosages. Farmers use over dosages of pesticides in many developing countries. The major reasons stated by the farmers for less use of pesticides were lack of funds, low pest incidence and lack of knowledge (Ngowi et al., 2007).

\section{Mixing of Pesticide}

Farmers in the survey applied pesticides by both single and mixed method. Few farmers (about 9 $\%$ apply one chemical at a time. However, majority of (91\%) the farmers applied the pesticides in mixtures (Fig. 3). Farmers believe that a "cocktail" application is always more effective and reduce labour cost (Jipanin et al., 2001).

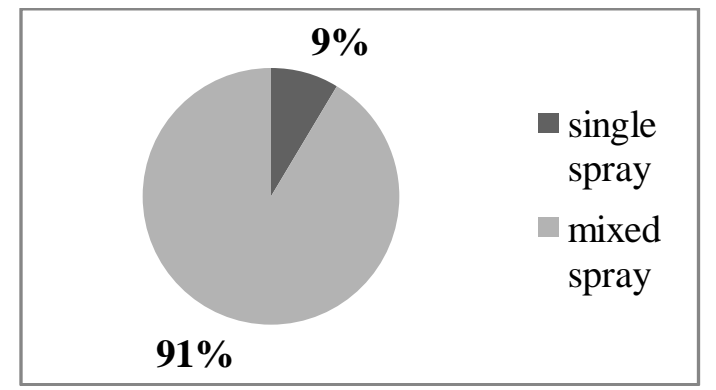

Fig. 3. Method of application practiced by the farmers

\section{Pre-harvest intervals}

It was noticed that more than $89 \%$ of the farmers in the selected GN divisions harvest the produce before the recommended pre-harvest interval (Fig. 4). Among the selected respondents, 100\% of farmers from Thettativu-south, Kaluthavalai-4 and Shanthipuram GN divisions harvest the produce before the period of pre-harvest interval. 


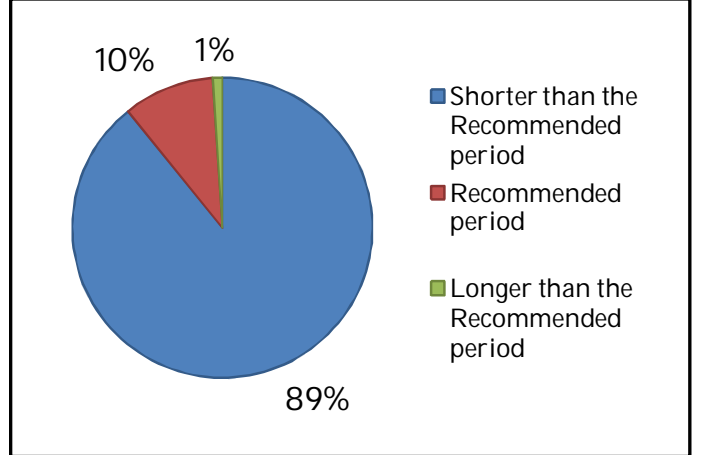

Fig. 4. Pre-harvest interval practiced by the farmers

In the study area, it is a regular practice to spray pesticides immediately before or after the harvest. When the pesticide spray was done immediately before harvesting, the danger of pesticide residue on produce was more ( $\mathrm{J}$ eyanthi and Kombairaju, 2005).

\section{Conclusion and Recommendations}

Findings of this survey highlighted that, the pesticide usage pattern in vegetable production in Manmunai South and Eruvilpattu Divisional Secretariat division of Batticaloa district, which is the major vegetable producing area of Batticaloa District. Farmers in the study area use heavy dosages of pesticides to protect their vegetable crops. The awareness of farmers related to pesticide usage is very less. Most of the farmers apply pesticide regularly to their crops irrespective of incidents of pests and crops diseases. Majority of the farmers use pesticides higher than the recommended level. Further, farmers mix more than one pesticide (Cocktails) to control many pest and diseases simultaneously and they do not know its effect on crop and environment. From this study, it could be concluded that, farmers in the Manmunai South and Eruvilpattu Divisional Secretariat division depend on chemical pest control method and use heavy dosages of pesticides. Therefore, awareness programmes are essential to change the attitudes of farmers to shift them to environment friendly pest control methods. It is essential for the sustainability of vegetable production in the study area and to safe guard the health of the people. The farmers need to be educated on the concepts of natural and organic farming for better yield and better health.

\section{References}

Anonymous. 2013a. Sri Lanka economy profile 2013. Index Mundi. Available at: http:/ / www.indexmundi.com/sri lanka/ ec onomy profile.html (Accesses on 28.11.2013)

Anonymous. 2013b. Statistical handbook of Batticaloa district 2012/2013. Batticaloa. District Planning Secretariat. 18p.

Dunham, D. 1995. Contract Farming and Export Horticulture: Can Agribusiness Revitalise the Peasant Sector in Sri Lanka? IPS Agricultural Policy Series, No. 3. Colombo. Institute of Policy Studies. $34 \mathrm{p}$.

Hummel, R.L., Walgenbach, J.F., Hoyt, G.D. and Kennedy, G.G. 2002. Effects of production system on vegetable arthropods and their natural Enemies. Agric. Ecosyst. Environ. 93 (1-3): 165- 176.

Illankoon, I.M.N., Abeynayake, N.R. and Kadupitiya, H.K. 2011. Forecasting vegetable extent and production in Sri Lanka: ARIMA model approach. Statistical Concepts and Methods for the Modern World. Available at: http:/ / at.yorku.ca/ c/b/d/h/29.htm (Accessed on 03.06.2013).

J eyanthi, H. and Kombairaju, S. 2005. Pesticide use in vegetable crops: frequency, intensity and determinant factors. Agril. Econ. Res. Rev. 18: 209-221.

Jipanin, J., Rahman, A.A., J aimi, J.R. and Phua, P.K. 2001. Management of pesticide use on vegetable production: Role of Department of Agriculture Sabah. 6th STE Research Seminar. pp. 1-21.

Legutowska, H., Kucharczyk, H. and Surowiec, J . 2002. Control of thrips infestation on leek by intercropping with clover, carrot or bean. Acta Hort. (ISHS). 579: 571-574.

Ngowi, A.V.F., Mbise, T.J., Ijani, A.S.M., London, L. and Ajayi, O.C. 2007. Pesticides use by smallholder farmers in vegetable production in Northern Tanzania. Crop Protection (Guildford, Surrey). 26 (11): 1617.

Varela, G. and Navarro, M.P. 1988. Influence of pesticides on the utilization of food. Bibl. Nutr. Dieta. 4: 40-54.

Vidanapathirana, R.P. 2008. Marketing margins of the domestic vegetable trade in Sri Lanka. Sri Lanka J. Agrarian Studies 12 (2): 36-60. 